\title{
FEDERALISME EN SEPARATISME IN WESTINDIE
}

\author{
DOOR
}

\section{W. R. Menkman}

Een dertigtal jaren geleden vertoonde zich op de Bovenwindsche Eilanden (noodlijdend) een beweging tot afscheiding van de rest der Nederlandsche Antillen, thans komt op Aruba (50.000 à 60.000 inwoners) een zelfde streven tot uiting. Verandering van vlag werd en wordt niet beoogd.

Tegenover dit separatisme stond en staat, in zeer duidelijke tegenstelling, de federatieve gedachte, met betrekking tot de Britsche West Indiën, thans opnieuw aan de orde gesteld.

Het vraagstuk wordt behandeld in een verzameling stukken, uitgegeven door het Colonial Office, onder den titel Closer Association of the British West Indian Colonies, in Mei van dit jaar aan het Parlement aangeboden.(Cmd. 7120 London, His Majesty's Stationery Office, ninepence net). In het voorbijgaan zij opgemerkt, dat in het Britsche imperium nog altijd plaats is voor koloniën. En, wat steekt er eigenlijk voor verwerpelijks in dit woord?

De publicatie, hier besproken, bevat twee boodschappen aan het Parlement, een van 14 Maart 1945 van den toenmaligen en een van 14 Februari 1947 van den lateren Secretary of State for the Colonies.

In het oudere staatsstuk wordt de kwestie der Westindische federatie genoemd één met een lange geschiedenis en verwezen wordt naar het plan eener vereeniging der Leeward en Windward Islands, indertijd door de West India Royal Commission aanbevolen. De minister van 1945 stelde als einddoel van iedere federatie volledig zelfbestuur, binnen het Britsche Gemeenebest. Zouden de diverse koloniale wetgevende colleges in principe het denkbeeld eener algemeene federatie aanvaarden, dan zou later een conferentie belegd kunnen worden, ten einde voorstellen tot een nauwere vereeniging te formuleeren. 
Uit de boodschap van 1947 blijkt, dat inmiddels in alle betreffende koloniën het vraagstuk besproken is; op de Bahamas stond men afwijzend tegenover iederen vorm van nauwere aaneensluiting der $\mathrm{Br}$. Westindische koloniën, overal elders (Barbados, Britsch Guiana, Britsch Honduras, Jamaica, Leeward Islands, Trinidad) verklaarde men zich bereid deel te nemen aan een conferentie, als voorgesteld, in de maand September van dit jaar.

De minister stelde nu voor, dat ieder gebied een klein aantal gedelegeerden aan zal wijzen en dat de vier leden der Britsche afdeeling van de Caribbean Commission uitgenoodigd zullen worden de conferentie bij te wonen, als waarnemers, tenzij in het geval dat een niet officieel lid dier afdeeling tot vertegenwoordiger van eenige kolonie zou benoemd worden. Volledigheidshalve zij hier aangeteekend, dat indertijd de C.C., waartoe thans, behalve de V.S. en Gr. Brittannië, ook Frankrijk en Nederland behooren, voorgesteld is als een niet-politiek, of a-politiek lichaam.

Nogmaals wordt er de aandacht op gevestigd, dat indertijd in het rapport der Royal Commission de vereeniging der Leeward en Windward Islands aanbevolen werd als een practische proefneming op het gebied der federatie. In Januari en Februari van dit jaar is dit project besproken in een bijeenkomst op Saint Kitts en toen is, met een groote meerderheid, instemming betuigd met een zoodanige federatie op beperkte schaal, met inachtneming der aanbevelingen van de R.C., voor wat betreft constitutioneele hervormingen en het instellen van een sterk centraal bestuur.

De minister acht het thans niet meer noodzakelijk, of zelfs wenschelijk, om de resultaten der kleine federatie af te wachten, $\mathrm{nu}$ er aanwijzigingen zijn dat men bereid is de vereeniging van alle $\mathrm{Br}$. Westindische koloniën, met uitzondering dan van de Bahamas, in overweging te nemen, een vereeniging waarin de Leeward en Windward Islands als één eenheid zouden optreden. De minister van 1945 had reeds de aandacht gevestigd op de moeilijkheid, onder moderne omstandigheden, voor kleine gebiedsdeelen, om volledige onafhankelijkheid te handhaven in alle bestuursaangelegenheden. Terwijl de zoozeer verbeterde communicatiemiddelen (vliegdienst) vereeniging vergemakkelijkt. Nadrukkelijk wees de bedoelde bewindsman er op, dat politieke en economische zelfstandigheid twee verschillende aangelegenheden zijn - en dat er naar gestreefd zou moeten worden 
te bewijzen dat de federale administratie het stellen kan zonder voortdurenden finantieelen steun van buitenaf. Ook zou rekening gehouden moeten worden met de betrekkingen van iedere individueele kolonie tot haar niet-britsche naburen, in welke federatie dan ook.

Aan de beschouwingen betreffende het federale vraagstuk zijn als bijlagen toegevoegd een overzicht van de constituties der onderscheiden Britsche Westindische koloniën, van de bevoegdheden der gouverneurs, de samenstelling en de macht van de uitvoerende en wetgevende colleges, alsmede van de regelingen van het kiesrecht. Het is opmerkelijk hoeveel verschil er bestaat ten opzichte van al deze punten. Waar tegenover gesteld kan worden de uniformiteit welke altijd betracht is, ten aanzien van óns koloniale staatsrecht; bij de formuleering der laatste Westindische staatsregelingen is blijkbaar zelfs rekening gehouden met de voor Nederlandsch Indië geldende normen.

Een ander bijvoegsel geeft de financieele posities, volgens laatste gegevens, van alle $\mathrm{Br}$. Westindische koloniën, behalve de Bahamas. De inkomsten liepen van 3 à $4 £$ tot bijna $55 £$, de uitgaven bewogen zich ongeveer tusschen dezelfde grenzen, de openbare schulden tusschen enkele ponden en $60 f$, alles per hoofd der bevolking.

Ten slotte wordt een overzicht gegeven der machtsverdeeling in Australië, Canada en India, waarschijnlijk ter vergelijking.

Het gouverneur generaalschap der Ned.Westind. bezittingen van 1828 bleek al spoedig geen practische combinatie te zijn; thans schijnt het denkbeeld eener federatie van de twee Britsche vastelands- en nagenoeg alle insulaire koloniën in tropisch Amerika uitvoerbaar geacht te moeten worden. In ons West Indië was de schepping van Koning Willem I alles behalve een federatie, terwijl het, wat het Britsche rijk betreft, tot het eind der vorige eeuw geduurd heeft, voordat de federale gedachte bewust in practijk gebracht werd (Federated Malay States). Om dan eindelijk in de allerlaatste jaren ook in ons staatsbestel, althans theoretsch, ingang te vinden, met betrekking tot NederlandschIndië, of Indonesië, zooals het thans vrij algemeen genoemd wordt.

Wat onze West aangaat, zou de gunstige factor der verbeterde verkeersmiddelen evengoed van belang zijn als zij dit ten opzichte van Britsch West Indië is.

Wordt het voorstel van den Engelschen minister aangenomen, 
dan zal de federatieconferentie op Jamaica gehouden worden. Het zal ook voor ons van groot belang zijn te vernemen, hoe de gedelegeerden der $\mathrm{Br}$. Westind. koloniën denken over de groote vraagstukken van centraal bestuur, financiën, wetgeving en rechtspraak, in een unie van continentale en insulaire, individueel zelfstandige territoria in tropisch Amerika, als onderdeel van het Britsche Gemeenebest.

September 1947. 